\title{
A Perspective on the Doctrine of the Separation of Powers based on the Response to Court Orders in Kenya
}

\author{
Emanuel Kibet E Kimberly Wangeci*
}

\begin{abstract}
The Constitution of Kenya provides that the sovereign power of the people shall be vested in the executive, the legislature and the judiciary, reflecting the democratic ideal that if power is concentrated in the hands of a few, it is prone to misuse. This provision aims to safeguard against arbitrary and capricious governance and the abuse of power. In the new constitutional order, there has been instances of tensions between the judiciary and the other arms of government. Unfortunate incidents of members of the Legislature referring to court orders as stupid and idiotic with blatant disregard for court orders have been witnessed. In a government whose legitimacy is vindicated by a court, it is ironical to observe a selective attitude towards respecting subsequent court orders. This paper aims to consider the disregard of court orders against the backdrop of the separation of powers and other relevant principles of constitutionalism.
\end{abstract}

\section{Introduction}

A scenario was painted of a society where there is no law and it is survival for the fittest, the mighty get their way while the feeble have no redress for the injustices they face. Thomas Hobbes stated that life in such a society without law was short, brutish and nasty.

The rule of law is a principle that ensures that such a situation does not exist, that all are equal before the law despite their might and valor. As A. V. Dicey conceptualizes it, not only is no man above the law but also every man should be subjected to the ordinary law. ${ }^{1}$

\footnotetext{
* The authors are post-graduate Diploma in Law students at the Kenya School of Law in Nairobi, Kenya.

1 Dicey AV, Introduction to the study of the law of the Constitution (1885).
} 
Whereas the legislative arm of government makes the laws, the judicial arm makes legal decisions on facts based on those laws. This brings up the question whether the Executive and the Legislature should be able to disregard court orders against the backdrop of having established that all men should be subjected to the law. A proper analysis of their defence that the Judiciary is overstepping its mandate by ignoring the concept of separation of powers will thus be analysed. It would be easy to say that the answer is a simple "no"; court orders are to be obeyed by all. Rightfully so, their obligation to respect and obey the court orders is premised and must be understood within the prism of the separation of powers.

\section{Separation of Powers}

This is a concept that can be traced back to the 16th century with Aristotle, Polybius, Cicero, St. Thomas Aquinas, and Machiavelli who all argued that mixed regimes of the one, the few, and the many were the best forms of regimes in practice because they led to a system of checks and balances. ${ }^{2}$ Baron de Montesquieu, who is widely quoted on the subject of the doctrine of separation of powers, suggested a pure separation of powers system. ${ }^{3}$ Van der Vyver, borrowing from Montesquieu, is of the opinion that separation of powers is composed of the following principles: ${ }^{4}$

i. The principle of trias polita, requiring a formal distinction between the legislature, executive and judicial branches.

ii. The principle of personnel according to which the same people should not be allowed to serve more than one branch of the government at the same time.

iii. Separation of functions between the three branches to avoid one interfering with or assuming the roles of the other.

iv. The principle of checks and balances that requires that each organ be entrusted with special powers designed to serve as checks on the exercise of functions by the others in order to come to an equilibrium.

Calabresi G and Berghausen E, 'The rise and fall of the separation of powers' 106 Northwestern University Law Review (2012).

Cooper S, 'Considering 'Power' in Separation of Powers' Standard Law Review (1994).

4 Van der Vyver JD, 'Political Power Constraints in the American Constitution' South African Law Journal (1987). 
In its simplicity, separation of powers denotes that power should not be vested in the hands of few, but clearly donated to three arms of government so that none should have excessive powers. Such a situation gave rise to the famous quote of Lord Atkin's that 'power tends to corrupt and absolute power tends to corrupt absolutely.'

With the promulgation of the Constitution of Kenya in 2010 there came clearer the separation of powers from the previous more powerful constitutional dispensation that had a President had unfettered powers to influence the Legislature and Judiciary. ${ }^{5}$ It was also augmented that Kenya had presidential absolutism. ${ }^{6}$ The people of Kenya delegate their sovereign power under the constitution to the Legislature, Executive and the Judiciary at both national and county levels. ${ }^{7}$

The constitution captures the principles elucidated by Van der Vyver, as have been described in the previous section. As regards formal distinction and precision of functions, the constitution is clear in Article 1(3) that the sovereign power of the people is delegated to the Legislature, Executive and Judiciary and goes on further to assign their functions.

Chapter 8 of the same constitution deals with the Legislature that derives its legitimacy from the people. ${ }^{8}$ The constitution is further very categorical that, 'no person or body, other than Parliament, has the power to make a provision having the force of law in Kenya except under authority conferred by this constitution or by legislation." It thus solely places the law-making function in the legislative arm.

The functions of the Executive are not easily pointed out and some scholars have argued that its functions are merely the residue of the functions of government after legislative and judicial functions have been carved out. ${ }^{10}$ That notwithstanding, chapter nine of the constitution has outlined the functions of the Executive, constraining itself to the narrow understanding of the Executive ${ }^{11}$

5 Ojwang JB, The Constitutional development in Kenya: Institutional adaptation and social change (1990), 41. He further states that the first amendment to the repealed Constitution gave the president unfettered discretion to appoint the Attorney General who was the head of prosecution, members of the Public Service Commission and others.

Onalo PL, An African appraisal: Constitution- making in Kenya, Trans Africa Press Publishers, 2004, 141. Article 1(3), Constitution of Kenya (2010).

Article 94(1), Constitution of Kenya (2010).

Article 94(5), Constitution of Kenya (2010).

Ambani J and Mbondenyi MK, The new Constitution of Kenya: Principles, government and human rights, Law Africa Publishing, 2013, 85.

11 Kapur AC, Principles of political science, 1996, 575. A narrow understanding of the executive refers only 
by looking at the different functions of the President, ${ }^{12}$ the Deputy President ${ }^{13}$ and the Cabinet.

Judicial authority refers to the powers vested in a tribunal to decide authoritatively and conclusively disputes between subjects of the State, or between the State and its subjects. ${ }^{14}$ This judicial authority is derived from the people and is vested in the courts and tribunals established by the court. ${ }^{15}$ In addition to the key guiding principle the courts and tribunals should consider, vital provisions of safeguarding independence of the Judiciary are provided. They include security of tenure, and remuneration as well as the proviso that the Judiciary is only subject to the constitution and the law and not subject to the control or direction of any person or authority. ${ }^{16}$

The second proposition by Van der Vyver is that no one person should serve in two arms of government at the same time and this has adequately been provided for in the constitution. For example, the President should not hold any other state or public office ${ }^{17}$ whereas in Section 3 of the repealed constitution, one of the prerequisites for one to be elected as president was that he had to be elected as a Member of Parliament. Article 152 (3) is categorical that a Cabinet Secretary shall not be a Member of Parliament whereas Ministers and Members of the Cabinet were to be appointed by the president from among the Members of Parliament in the old order. ${ }^{18}$

The idea of checks and balances is part and parcel of the doctrine of separation of powers and probably the most controversial precept that is also reflected in the constitution. It refers to the restraints which operate between the different institutions of government in order to guard against abuses of powers. ${ }^{19}$ Article 10 provides that among the national values and principles of governance are good governance, integrity, transparency and accountability. The legislature, for instance, checks the executive through reserving the power to impeach a President, ${ }^{20}$ while the Executive, on the other hand, checks the Leg-

to the Chief Executive Head of State and his advisers and ministers.

12 Article 132, Constitution of Kenya (2010).

13 Article 147, Constitution of Kenya (2010).

14 Currie and De Waal, The New Constitutional and Administrative Law, (2001) 268.

15 Article 159, Constitution of Kenya (2010).

16 Article 160, Constitution of Kenya (2010).

17 Article 131(3), Constitution of Kenya (2010).

18 Section 16(2), Repealed Constitution.

19 Carrol A, Constitutional and administrative law, Longman Publishers, 2007, 39.

20 Article 145, Constitution of Kenya (2010). 
islature through presidential assent of a Bill into law. ${ }^{21}$ The Judiciary on its part checks the Executive and Legislature through its power of judicial review. ${ }^{22}$ This is in line with idea postulated by Montesquieu that 'le pouvoir anête le pouvoir' meaning that power should check power.

\section{Analysis of Case Law}

Having understood the doctrine of separation of powers the question to be answered then is whether the Executive and Legislative arms of government should have the discretion of obeying or disregarding court orders. The courts in Kenya have on a number of occasions been called upon to answer this pertinent question as it is not expected that everyone will be happy and ready to follow court orders. Regarding this pertinent question there is rich jurisprudence.

Justice GV Odunga in Judicial Service Commission v Speaker of the National Assembly and the Attorney General linked obedience of court orders to the rule of law. ${ }^{23}$ He drew attention to Article 10(1) of the constitution that binds all state organs, state officers, public officers and all persons when applying and interpreting the constitution, enacting, making or implementing any public policy decision. The said principles under Article 10(2) include the rule of law. Respect of court orders, however disagreeable, is a tenet of the rule of law. He stated that where a person feels that a particular order is irregular, he may lodge an appeal in a higher court. He was of the opinion that when the decision to obey particular court orders is left to the whims of the parties, public disorder and chaos are likely to reign supreme yet under the preamble to our constitution we (do) recognize the aspirations of all Kenyans for a government based on the essential values of human rights, equality, freedom, democracy, social justice and the rule of law.

Honourable Lenaola was adamant that court orders must be obeyed at all costs whether one agrees with them or not. ${ }^{24}$ In his opinion and the position of the law on the same is that if one is dissatisfied with a court order he or she ought to move the court as appropriate. Blatant disregard of court orders is thus an underestimation and belittlement of the institution.

\footnotetext{
21 Article 115, Constitution of Kenya (2010).

Article 115, Constitution of Kenya (2010).

Judicial Service Commission v Speaker of the National Assembly and the A.G (Petition 518 of 2013) eKLR Kariukie 2 Others v Minister For Gender, Sports, Culture \& Social Services \& 2 Others (2004) 1 KLR 588
} 
While the law is clear that when it comes to parties to a suit, when the question is whether the law should bend to you or you should bend to the law, ${ }^{25}$ the latter is true; one may wonder whether the rules apply mutatis mutandis to the Executive and the Legislature.

Since the Kenyan nation has chosen the path of democracy rather than dictatorship, the courts must stick to the rule of law even if the public may in any particular case be of a contrary opinion. The courts must continue to serve justice to all irrespective of their status. ${ }^{26}$

The courts should never abandon their role in maintaining the balance. ${ }^{27}$ In Njenga Mwangi \& Another v the Truth, Justice and Reconciliation Commission \&o 4 others, ${ }^{28}$ the court stated that it can delve into the constitutionality, or the lack of it, of actions of members of the Legislative.

Disregard of court orders is tantamount to contempt of court; an offence that is punishable not to uphold the ego of the judicial officer but to safeguard the rule of law and fundamental to the administration of justice. ${ }^{29}$ In Johnson $v$ Grant, L J Clyde noted,

'The phrase 'contempt of court' does not in the least describe the true nature of the class of offence with which we are here concerned. . The offence consists in interfering with the administration of the law; in impending and perverting the course of justice. . . it is not the dignity of court which is offended - a petty and misleading view of the issues involved, it is the fundamental supremacy of the law which is challenged'

In the foregoing, it is clear thus that it is mandatory to obey court orders despite the rank, the might and muscle one may have. To blatantly disregard court orders sets a bad precedent and cultivates a lack of belief in the courts on the part of the people from whom it derives its authority. ${ }^{30}$ The principle of rule of law means that all persons, including all organs of government, must be

25 As early as 1778 , Chief Justice McKean of the United States, when dealing with a case of a party in civil litigation who refused to answer interrogatories, is noted to have stated, "Since however, the question seems to resolve itself into this, whether you shall bend to the law, or the law shall bend to you, it is our duty to determine that the former shall be the case." In the history of contempt of Court (1927) P 47.

26 Murungaru v Kenya Anti-Corruption Commission \& another [2006] 1 KLR 77.

27 Keroche Industries Limited. Kenya Revenue Authority \& 5 Others Nairobi [2007] KLR 240.

28 Njenga Mwangi\& Anotherv the Truth, Justice and Reconciliation Commission \& 4 Others, Nairobi High Court (2014) eKLR.

29 Teachers Service Commission v Kenya National Union of Teachers \& 2 others (2013) eKLR.

30 This can lead to a state of anarchy as was witnessed in the 2007 post-election violence where the polity had lost faith in the judiciary to administer justice and prosecute the perpetrators of the violence. 
guided by the law which must apply equally to all persons. Judicial orders granted in exercise of judicial authority by the courts should therefore be applied indiscriminately.

The choice to disregard or disobey the law is a threat to the legitimacy and credibility of the constitution and the rule of law. One of the obvious consequences would be that there would be no judicial credibility and the citizens would be left with no legal recourse for any injustice suffered from the arbitrary exercise of power and would have to resort to self-help measures, a clear recipe for anarchy.

\section{Circumstances when the Court may not Interfere with the Other Arms of Government}

Article 2 of the constitution declares it to be the supreme law of the land and binds all persons and organs of the state. Further, no person may claim to exercise state authority unless authorized by the constitution. Constitutional supremacy then places a special role on the judiciary in checking the constitutionality of all acts carried out by the other organs of the government as well as private actors. In exercising judicial authority, the courts are to be guided with the principle of protecting and promoting the purpose and principles of the constitution. ${ }^{31}$ The Kenyan High Court in Trusted Society of Human Rights and others $v$ Attorney-General and others has already acknowledged the authority of the courts under the new constitution, noting that 'the courts have an interpretative role including the last word in determining the Constitutionality of all governmental action. ${ }^{32}$ Justice Ojwang reiterated this position noting that the constitution cannot propel itself and as such the court have the special role of interpreting the constitution as the final arbiter, pronouncing with finality the legality of state action. $^{33}$

First, through the power of judicial review, the Judiciary may at any instance, based on an application, issue orders accordingly to restrain the Legislature or the executive. The courts cannot, however, or should not, overrule the actions, policies and laws of the other arms of government in a way that unjus-

\footnotetext{
31 Article 159 (2)(e), Constitution of Kenya (2010).

Trusted Society of Human Rights and others v Attorney-General and others[2012] eKLR.

Ojwang JB, Ascendant Judiciary in East Africa: Reconfiguring the Balance of Power in a Democratizing Constitutional Order (2013), 39.
} 
tifiably disregards the doctrine of separation of powers. This has in the recent past inspired the rise of a phenomenon commonly referred to as judicial activism. It arises when the judiciary issues orders, which when weighed against the Constitution, go against the separation of powers doctrine. Oscar defines judicial activism as 'an action of the courts to overrule the actions, policies and laws of the other arms of government in a way that unjustifiably disregards the doctrine of separation of powers. ${ }^{34}$

Inevitably there will be jurisdictional conflicts between the three arms of government. Navigating through the doctrine of separation of powers, the courts may be faced with the challenges of when they should and when they should not give orders that contravene this doctrine.

\section{The Courts and the Legislature}

One of the most controversial decisions by the courts with regard to the legislature is Martin Nyaga Wambora and the County Government of Embu v Speaker, County Assembly of Embu \& 4 others (2014). The court gave orders restraining the $4^{\text {th }}$ respondent, the Speaker of the Senate, from proceeding with any motion for the removal of the petitioner and the Deputy Governor. The decision sparked off the question whether the control of the internal arrangements of Parliament which are areas of legislative competence, are subject to examination by the Judiciary. ${ }^{35}$ Upon whether or not the court had jurisdiction to intervene on matters that intrude into the functions of other state organs, the court in its decision in the matter stated that under Article 165 (3) (d), the court has jurisdiction to hear any matter relating to any question with respect to the interpretation of the Constitution including the determination of contravention of the constitution and any matter relating to the constitutional relationship between the levels of government.

The court in Wambora's case did defend its jurisdiction to determine matters affecting the legislature or the executive and stated;

\footnotetext{
34 Sang O, 'The Separation of Powers and new Judicial Power: How the South African Constitutional court plotted its course', Elsa Malta Law Review (2013).

35 The court explained in Wambora's case that notwithstanding parliamentary sovereignty, it had jurisdiction to hear the matter, stating "The thrust of the application and the petition as contended by the Petitioner, is that there have been violations of his Constitutional rights as enshrined under the Constitution by the County Assembly and the Senate. As such, I find and hold that the court, clothed with the above mentioned Constitutional provisions, is seized of jurisdiction to entertain the suit and the application herein."
} 
'This court is acutely aware that the three arms of government, that is to say, the Executive, the Legislature and the Judiciary have their respective mandates clearly set out in the Constitution and that, as far as possible, each arm of Government must desist from encroaching on the functions of the other arms of government. In fact, the court's position has always been that it can only interfere with the exercise of the Executive and the Legislature's mandates if it is alleged and demonstrated that they have threatened to act or have acted in contravention of the letter and spirit of the constitution.'

In this particular matter, the court distinguished the constitutional powers of the Senate and the county assemblies to impeach the Governor, but was very clear that the court involved itself only in determining whether the process of doing so was constitutional or not. ${ }^{36}$ Lenaola $\mathrm{J}$ in Njenga Mwangi \& Another v The Truth, Justice and Reconciliation Commission \& 4 Others in answering whether the court has the power to inquire into the constitutionality of the actions of the Speaker and other officers of the National Assembly answered in the affirmative as follows:

'I am also in agreement, that under section 29 of the National Assembly (Powers and Privileges Act) (Cap 6), courts cannot exercise jurisdiction in respect of acts of the Speaker and other officers of the National Assembly but I am certain that under Article 165(3) (d) of the constitution, this court can enquire into any unconstitutional actions on their part. ${ }^{37}$

Interestingly, the critics of this court's involvement in legislative functions have disregarded the integral role courts play in situations where there is conflict within the legislature itself. In the case of the Speaker of the Senate and another $v$ The Attorney General and others, the Supreme Court of Kenya observed that the court must or should always come in when it is called upon to, to ensure that parliament or the executive is operating within the constitution. ${ }^{38}$ And when its the court's opinion that it is not what, the court may give orders accordingly.

\section{The Courts and the Executive}

There have been several instances when the court has stopped or nullified the decisions of the executive. A case in point is Judicial Service Commission v Speaker of the National Assembly \& another in which the petitioners sought, among other petitions, that pending the hearing and determination of the substantive

\footnotetext{
Njenga Mwangi \& Another $v$ The Truth, Justice and Reconciliation Commission \& 4 Others [2013] eKLR. Njenga Mwangi \& Another $v$ The Truth, Justice and Reconciliation Commission \& 4 Others [2013] eKLR. Speaker of the Senate and another and the Attorney General and others, Advisory Opinion No.2 of 2013.
} 
constitutional petition an order be issued restraining the national assembly or the Departmental Committee of Justice and Legal Affairs from presenting to the President or forwarding the petition filed by Riungu Nicholas Mugambi seeking the removal of six commissioners of the Judicial Service Commission. ${ }^{39}$ The court ordered that;

'The six commissioners of the Judicial Service Commission, who are the subject of the petition filed by Riungu Nicholas Mugambi, shall not be suspended or removed from the office as such commissioners based on the said petition pending the hearing and determination of this petition or until further orders of the court.'

Initial orders by the court restraining the National Assembly had been ignored by the National Assembly. In this instance, the court restrained the Executive from removing the six commissioners from office protesting the blatant disobedience of court orders by the National Assembly. The court stated

'By ignoring court orders, the respondents would be sending wrong signals not only to the people of Kenya from whom they derive their authority but also to the whole world that they do not believe in the rule of law. When constitutional safeguards provided under Article 47 of the constitution are destroyed by being whittled at and judicial officers are put under the sufferance of the Executive or at the whims of the Legislature, the independence of the Judiciary is the first victim. It must always be remembered that under Article 25 of the constitution one of the rights and fundamental freedoms which cannot be limited is the right to a fair trial. Accordingly the courts are empowered to investigate allegations of abuse of power and improper exercise of discretion as well as the right to fair hearing or trial which in essence are what the petitioner allege.'

The court associated itself with the decision of Hon. Mr. Justice Lenaola, in Karinki \& 2 others v Minister for Gender, Sports, Culture \& Social Services \& 2 other$s^{40}$ where he expressed himself as follows:

'The instant matter is a cause of anxiety because of the increasing trend by Government Ministers to behave as if they are in competition with the courts as to who has more "muscle" in certain matters where their decisions have been questioned, in court! Courts, unlike the politically minded minister, are neither guided by political expediency, popularity gimmicks, chest-thumping nor competitive streaks. Courts are guided and are beholden to law and to law only! Where Ministers therefore by their actions step outside the boundaries of law, courts have the Constitutional mandate to bring them back to track and that is all that the courts do. Judicial review orders would otherwise have no meaning in our laws. . Court orders must be obeyed whether one agrees with them or not. If one does not agree with an order, then he ought to move the court to discharge the same. To blatantly ignore it and expect that the court would turn its eye

39 Judicial Service Commission v Speaker of the National Assembly \& another [2013] eKLR.

40 Kariuki\& 2 Others v Minister For Gender, Sports, Culture \& Social Services \& 2 Others [2004] 1 KLR 588. 
away is to underestimate and belittle the purpose for which courts are set up... If those who have knowledge of court orders and also have knowledge that the way to avoid those orders is to avoid personal service are sleeping well in the guise that by hiding behind the shield of muscle'

If the executive violates the procedural requirements of the supreme law of the land, it is for the courts of law to assert the authority and supremacy of the Constitution. However, there are certain matters that are pre-eminently within the domain of the executive, for instance, the courts may not make orders that impact on state policy. The courts may not involve themselves in policy formulation, and in instances where the constitutionality of the policies of the executive are challenged, the courts give orders accordingly only to the extent of the unconstitutionality of such policy. This must be done carefully without discrediting the legitimate function of the executive from formulating such policies.

In the Judicial Service Commission case, the court acknowledged the tension with regard to the doctrine of separation of powers and the relationship between the arms of government and state organs in the execution of their respective mandates under the constitution. In this petition, the petitioners sought, among other petitions, a declaration that the appointment of the $3^{\text {rd }}$ to $6^{\text {th }}$ respondents by the President as members of the tribunal contemplated under Article 251(4) was null and void. This posed a challenge to the distinctive role of the executive arm and the limits of the Judiciary in interfering with the President's role under the Constitution. In the aforementioned petition, the court relied on an observation by the Supreme Court of Zimbabwe in Smith v Mutasa that the Judiciary should not interfere in the processes of other branches of government unless it is mandated to do so by the constitution. ${ }^{41}$

\section{A Jurisdictional Comparison}

Many states have included the separation of powers doctrine in their constitutions. Consequently, noting the important role the judiciary plays in ensuring that the constitution is upheld. The critics of this influential power of the judiciary have argued that since judges and the entire judicial arm are not elected they cannot purport to substitute their interpretations of the constitution for those of the elected Legislature and the Executive. ${ }^{42}$

41 Smith v Mutasa [1990] LRC 87.

42 Tushnet M, Weak Courts, Strong rights: Judicial Review and Social Welfare Rights in Comparative Constitutional Law, Princeton University Press, 2008. 
As has been outlined, the doctrine of separation of powers is not aimed at having one arm supersede the other, but to have each one independent, free from control of another and to exist harmoniously within the rule of law. ${ }^{43}$ Kenya, being among the new constitutional democracies, has a lot to learn from developed and developing states in the context of the separation of powers doctrine.

\section{i. The South African Perspective}

In South Africa, the doctrine of separation of powers curtails the exercise of political power in order to prevent its abuse. As a consequence, the idea of checks and balance allows other branches of government a measure of oversight over the functions of the other branches. In the land-mark case Doctors for Life, the constitutional court of South Africa wrestled with the question whether the control of parliamentary internal arrangements, proceedings and procedures which are areas of legislative competence, are subject to evaluation by the court. ${ }^{44}$ The applicants in this particular case challenged parliament for passing Bills relating to issues of health on the grounds that the legislature had failed to fulfill its constitutional obligation of facilitating public participation during the process. The court acknowledged the constitutional role of parliament to make laws and that the judiciary could not interfere in any way with the proceedings and internal arrangements of Parliament. Nevertheless, the court went on to hold that passing of the Bills was unconstitutional because it contravened the constitutional process. The court stated;

'...under our constitutional democracy, the constitution is the supreme law. It is binding on all branches of government and no less on Parliament. When it exercises its legislative authority, Parliament 'must act in accordance with, and within the limits of the constitution; and the supremacy of the constitution requires that 'the obligations imposed by it must be fulfilled. Courts are required by the constitution 'to ensure that all branches of government act within the law' and fulfill their constitutional obligations.'

In finding that the Act of Parliament in question was unconstitutional, the court based its decision on the ideal of participatory democracy as an essential Constitutional obligation and not on the questioning of the legislative

43 Waldron J, "Separation of Powers in Thought and Practice?" essay delivered as a Clough Distinguished Lecture in Jurisprudence at Boston College on 20 September 2012. Jeremy emphasizes that it is one of a close-knit set of principles that work both separately and together as touchstones of institutional legitimacy. He also indicates that separation of powers principle requires the ordinary concurrence of one governmental entity in the actions of another, and thus permits one entity to check the actions of another.

44 Doctors for Life International v Speaker of the National Assembly [2006] ZACC 11. 
power of Parliament. The court relied on separation of powers to lessen its level of scrutiny of the legislation, and involve itself only in the constitutionality of the process of making such laws. In De Lille $v$ Speaker of the National Assembly, the High Court held that courts may determine whether the internal procedures adopted by the national assembly are consistent with the provisions of the constitution.

Court decisions in South Africa, unlike in Kenya, have been respected and upheld by the legislature. Although the court may not direct that parliament moves to amend the unconstitutional laws, parliament has done so to meet the constitutional obligation of enacting laws. ${ }^{45}$ The court shielded itself from direct confrontation with the political branches of government which has made it easier for the court to make decisions of constitutional principle while maintaining its legal legitimacy. This strategy has been helpful in promoting the institutional strength of the political branches of government in South Africa's young democracy.

\section{ii. United Kingdom's Perspective}

In the UK, the executive and legislature are closely entwined. The Prime Minister and a majority of his or her Ministers are Members of Parliament and sit in the House of Commons. ${ }^{46}$ The executive is therefore present at the heart of Parliament. The Executive comprises the Crown and the government, including the Prime Minister and Cabinet Ministers. It formulates and implements policies. The Legislature comprises the Crown, the House of Commons and the House of Lords. On the other hand, the Judiciary comprises the Judges in the courts of law, those who hold judicial office in tribunals and the lay Magistrates who staff the magistrates' courts. As a means of implementing the separation of powers doctrine, judges are prohibited from vying for elective seats to parliament under the House of Commons (Disqualification) Act 1975. ${ }^{47}$ As a result, the judicial arm of

45 Judge Phineas M Mojapelo, 'The Doctrine of Separation of Powers (a South African perspective)', Paper delivered at the Middle Temple South Africa Conference, September 2012. In this paper, Phineas, Deputy Judge President of the Southern Gauteng High Court argues that the foundational principle of the courts is to apply the law and not to make it. He adds that courts have specific power to review legislation and to develop the common law in order to align it with the Constitution and in the interest of justice. Courts may however not make laws outside the specific authority granted by the Constitution. The Constitution is the supreme law and conduct inconsistent with it is invalid to the extent of inconsistency.

46 Lord Phillips of Worth Maltravers, Judicial Independence and Accountability: A view from the Supreme Court', Gustave Tuck Lecture, 8 February 2011, 23.

47 House of Commons (Disqualification) Act. 
government has been held in high regard and court decisions taken effectively in the spirit of separation of powers.

In the Jackson case in 2005 the House of Lords questioned the relationship between parliamentary sovereignty and the rule of law, suggesting that there were limits to sovereignty where Constitutional fundamentals were at risk. ${ }^{48}$ This brings a situation where the courts are also seen to involve themselves in Constitutional questions. Professor Bogdanor, in a human rights paper, has argued that the Human Rights Act necessitated a compromise between two doctrines: the sovereignty of Parliament and the rule of law, and that the compromise depends upon a sense of restraint on the part of both the Judges and of Parliament. ${ }^{49}$ In doing so, the judiciary must be respected and entitled to interpret and uphold the rule of law where it is called upon to do so. This is a scenario which, besides the differential approach of the separation of powers doctrine, states have acknowledged the judicial role in determining the constitutionality of the legislations by Parliament. This also reinforces the universal ideal that citizens may only challenge the legitimacy of the actions of the Executive and the Legislature before an independent judiciary. In Secretary of State for the Home Department v JJ (2008), the House of Lords ruled that an 18-hour curfew amounted to a breach of liberty, and seeing that delegated powers cannot override the Human Rights Act, the control order imposed was ultra-vires and therefore was reversed by the Judge..$^{50}$ This shows that the Judges can effectively reverse ministerial action that is ruled beyond its power and check executive power, on a constitutional basis.

The judicial scrutiny function with regard to the Executive is to ensure that any delegated legislation is consistent with the scope of power granted by Parliament and to ensure the legality of government action and the actions of other public bodies. Similarly in $A v$ Secretary of State for Home Department, concerning the detention without charge of suspected international terrorists, the Attorney General argued that they were matters of a political character calling for an exercise of political and not judicial judgment and that it was not for the courts to usurp authority properly belonging to the executive. ${ }^{51}$ However, Lord Bingham rejected this argument, stating:

48 Jackson v Her Majesty's Attorney General [2005] UKHL 56.

49 Professor Vernon Bogdanor, Human Rights and the New British Constitution, Justice Tom Sargant memorial annual lecture, 2009 www.justice.org.uk.

50 Secretary of State for the Home Department v JJ [2008].

51 A v Secretary of State for Home Department [2004] UKHL 56. 
'The function of independent Judges charged to interpret and apply the law is universally recognized as a cardinal function of the modern democratic state and the Attorney General is wrong to stigmatize judicial decision-making as in some way undemocratic.'

\section{Conclusion and Recommendation}

As discussed above, it is evident that Montesquieu's thinking has served as a sound and brilliant practical guideline for the prevention of concentration of power. As observed, it is inherently impossible to achieve an absolute separation. The process of judicial review is therefore vital in checking the power of government, especially as regards the use of statutory instrument. As an inseparable part of the evolution of democracy, separation of powers doctrine promotes a system of checks and balances existing among the three organs of the government to ensure a strong nurtured democratic system.

Threats and attempts by the legislature to cut down Judiciary funding is a show of intolerance and vengeance against the Judiciary for their 'unfavorable' orders. ${ }^{52}$ This guarantees that only if and when the three arms of government work in understanding their constitutional role, and not self-interest, the doctrine of separation of powers may not serve its intended purpose. Judges and judicial officers have sworn a solemn oath to diligently serve the people, and to impartially do justice in accordance with the constitution, the law and the customs of the Republic without fear, favor, bias, affection, ill-will, prejudice or any political, religious or other influence.

Respecting the rule of law calls upon everyone, indiscriminately, to respect the institution that interprets the law. As expected, there are many instances when the courts make decisions that certain sections of the population do not agree with, but the rule of law means that we cannot choose which court orders to obey and which not to obey. Doing so will be an abdication of duty to respect and uphold the law. Interpretation of the law, even among judges, may differ. It is the recognition of the fact that in exercising his/her judicial powers a judge may err that an appellate process exists in courts set out in the Constitution. The legal system has an inbuilt review and evaluation mechanism that exists solely for the purpose of appeals and other jurisdictional matters. These instruments of

52 Chagema A, the $11^{\text {th }}$ Parliament has become a Disgrace, Standard News Digital, 6 June 2015 http:// www.standardmedia.co.ke/Article/2000164736/the-11th-parliament-has-become-a-nationaldisgrace on 20 November 2015. 
justice must be explored in full if a court order is unfavorable in preference to disobedience and disregard of such orders.

The Judiciary must also function with caution, and respect the political boundaries so as to maintain public trust. In an historical setting, the Supreme Court decision in the presidential petition displayed public trust in the judiciary to accept the court's determination amidst political intolerance. To raise and sustain this record, the courts must refrain from engaging in a political tussle. The Judiciary must be pragmatic and vigilant of politicians who may taint the hardearned image of a credible judiciary.

Lastly, the three arms of government must lead by example by showing dignity and respect for the rule of law. This includes institutional conduct with integrity and transparency aimed at protecting and upholding the constitution at all times pursuant to the oath of office. This way, other institutions will follow suit to defend the rule of law in a manner that promotes the aspirations of a democratic republic. 